\title{
'Our hurtless mirth': What's Funny about The Dutch Courtesan?
}

\begin{abstract}
This paper reflects on the performance work of the Toronto Dutch Courtesan to explore what is potentially funny in the play and how this comic potential might reveal inequities filtering through misogyny, religious intolerance, and xenophobia. Marston's play operates in a series of comic registers eliciting a range of emotional responses from audiences - from cruel laughter to cathartic pathos to light-hearted pleasure to anxiety. While the play's critical and moral 'point' is impossible to pin down, the Toronto Courtesan demonstrated the capacity of the play's comic ambiguity to critique social inequity and to invite audiences to ask reflectively: what are we laughing at and why?
\end{abstract}

In February 2019, the cast of the Toronto Dutch Courtesan project sat down for their second table read. The participants formed a mixed group of amateur and seasoned actors; many of them had worked with Shakespearean plays before, while a few had performed in medieval mystery and Elizabethan touring plays produced by Toronto's Poculi Ludique Societas company. None of the cast had previously worked with Marston's drama and its uneasy blend of satire and clowning. This rehearsal offered the first opportunity for the cast to work with one of the play's editors and production dramaturges, and the actors had many questions. Many members of the cast were in the early stages of working out who their characters were in the play's story; some — including Andrew Eldridge, the production's Freevill — seemed simultaneously puzzled by and uncomfortable with the play's main sources of humour: the testing of women's fidelity; jokes at the expense of foreigners, sex workers, and religious 'others'; and the literal gallows humour of the play's final act where two men (Mulligrub and Malheureux) are framed — and nearly hanged — for theft and murder. Amidst sarcastic laughter at moments where the xenophobia and misogyny of The Dutch Courtesan

Erin Julian (Erin.Julian@roehampton.ac.uk) is a postdoctoral fellow for the Engendering the Stage project at the University of Roehampton, London. She was a dramaturge for the Toronto Courtesan. 
appeared a shade too recognizable, ever more questions arose about what the tone of this play was. What was its satirical point? The reading unfolded into a discussion of what, precisely, is funny about The Dutch Courtesan.

These production questions were pertinent to the 'Strangers and Aliens in London and Toronto: Sex, Religion, and Xenophobia in Marston's The Dutch Courtesan' project, whose goals included exploring the themes of intolerance related to sex work, gender, religion, and the 'foreign' as means to better understanding these problems in Marston's play and early modern English culture as a whole. The project also explored how these themes resonated across the early modern to the contemporary stage. What can staging The Dutch Courtesan teach us about how Marston's play works on its feet, and how audiences might have interpreted it in its own day? What does a modern-day production of Marston's play, performed at a theatre in the centre of one of Canada's most diverse cities, reveal about intolerance in our present day? Addressing the question 'what's funny about Marston's Dutch Courtesan' challenges audiences and actors but is essential to addressing how the play takes up cultural attitudes towards foreigners, women, and sex workers in early modern London.

\section{Interpreting Laughter}

Humour and laughter are notoriously difficult subjects to theorize because they are so unstable. In his substantial introduction to Laughter in the Middle Ages and Early Modern Times, Albrecht Classen circles repeatedly around the problem of laughter's ambiguity. Classen's substantial introduction, which includes both an original survey of classical, medieval, and early modern philosophies of laughter and a thematic review of the collection's individually authored chapters, reflects laughter's resistance to interpretation. Classen observes, for example, that laughter is both an affront to Christian sobriety and an appropriate reaction to the mystery of God; a means of illuminating oppression and violence and a means of causing it; a sign of health and a sign of illness; a means of bringing communities together and of rending them apart. ${ }^{1}$ Thinkers like Aristotle, Sir Philip Sidney, and Laurent Joubert endorse a prescriptive view of laughter that suggests individuals can control how they respond to the comic by refusing to laugh at 'boorish' subjects; ${ }^{2}$ in contrast, Henri Bergsen and Sigmund Freud, the two figures who have arguably most influenced modern theories of comedy and laughter, posit that laughter is mechanical, spontaneous, and involuntary, and thus resists prescriptive ethical approaches. ${ }^{3}$ Most critical work on the subject agrees that laughter is not only an inherently social phenomenon, but is also harshly divisive. True jokes, to Freud, 
are 'tendentious' and either 'hostile' or 'obscene', with 'the one who makes the joke' making another into 'the object of the hostile or sexual aggressiveness' for the pleasure of an observing third party. ${ }^{4}$ Freud roots jokes and laughter in violence in a model that unnervingly fits how Marston's Dutch Courtesan operates with tricksters like Freevill and Cocledemoy aggressively humiliating Malheureux and Mulligrub (among others) for the arguable pleasure of the audience members who are perhaps united via their laughter at the suffering dupes. ${ }^{5}$

The violent potential of humour will be familiar to many of us who have ever laughed in a theatre, and goes a long way to explaining why critical works on the subject frequently couple laughter and humour with anxiety. In Classen's Laughter, multiple chapters flag laughter as potentially infelicitous in their very titles: laughter is 'uneasy', connected with the 'inappropriate', the 'ambigu[ous]', the 'problem[atic]', and the 'transgressi[ve]. ${ }^{6}$ We commonly accept laughter as a nervous, almost 'hysterical' response to uncomfortable situations. ${ }^{7}$ In theatres it may be shared by actors and audiences as both pain and relief from embarrassment or other discomfort. ${ }^{8}$ I know that my own laughter at the Toronto Courtesan could certainly be characterized as frequently anxious and painful: I laughed angrily at Freevill's unabashed pride in his plottings against his best friend, future bride, and former mistress; I worried about the potential inappropriateness of the play's xenophobia and misogynist jokes in a modern context; I laughed nervously at the possibility that others laughing around me may have been experiencing those same jokes as in earnest; I laughed guiltily at the vintner Mulligrub's repeated misfortunes. My laughter was never unmixed or easy.

In Emotional Excess on the Shakespearean Stage, Bridget Escolme balances our critical preoccupation with anxious laughter with the comic pleasures of early modern comedy. She attends to early modern religious texts, conduct books, essays, and anti-theatrical pamphlets (including Thomas Wright's Passions of the Mind in General, Philip Sidney's Apology for Poetry, and Robert Burton's Anatomy of Melancholy) that articulate laughter as a source of anxiety and danger for early modern people, who were enjoined to control their emotions by subjecting them to 'reason and restraint', balancing their humours, and avoiding provocative theatre. But she also (rightly I think) assumes that 'the large number of people who attended the theatre in early modern London got pleasure from watching and hearing excesses of even distressing passions such as anger and grief.' Escolme's work, importantly, reminds us to take seriously what might be truly pleasurable in Marston's play — what is joyfully witty or full of beautiful pathos. Ultimately, these moments of wit and pathos set off and heighten what is troubling elsewhere in the play. 
This paper reflects back on the rehearsal and performance work of the Toronto Dutch Courtesan production to explore what is potentially funny in the play, how it is funny, and how this comic potential might be used to explore misogyny, religious intolerance, xenophobia, and violent attitudes toward sex work. The paper also considers some of the risks of undertaking such explorations. Marston's play operates in a series of comic registers, found in clown plays, morality drama, and satirical city comedy, that elicit a layered range of emotional responses from audiences - from cruel laughter to cathartic pathos to light-hearted pleasure to anxiety. While the play's critical and moral 'point' is impossible to pin down, the Toronto Dutch Courtesan demonstrated the rich capacity of the play to critique social inequity. But the most productive effect of the play's multidirectional and ambiguous modes of operation is precisely that it invites us to ask reflectively: what are we laughing at, and why? What exactly is funny about Marston's Dutch Courtesan?

\section{'Our hurtless mirth’? Mulligrub, Cocledemoy, and Comic Violence}

In a speech that functions as the epilogue to the play, Cocledemoy has the final word in its framing. 'If with content our hurtless mirth hath been / Let your pleased minds, as our much care, be seen' $(5.3 .175-6),{ }^{10}$ he instructs the audience, offering the conventional invitation to applaud if the play has provided pleasure. The invitation perhaps jostles the play's final scene uncomfortably: we have just seen two men - the play's dupe Mulligrub and Freevill's friend Malheureux brought near the point of execution, both for crimes that they arguably did not commit. (Cockledemoy frames Mulligrub for stealing his cloak; Freevill fakes his death leaving Malheureux suspected of and condemned for murder.) This same scene shows the Dutch courtesan, Franceschina, herself sent off stage to 'severest prison'; one act earlier, we also witnessed Beatrice's distressed grief at the false reports of Freevill's death. The question of whether the play's mirth has been 'hurtless' is very much in the eye of the beholder.

In a rudimentary sense, audiences readily understand Cocledemoy's meaning. Franceschina has been taken off to jail, yet she possibly deserves her punishment, given that she has spent the second half of the play trying to urge Malheureux to actually commit the murder for which he is framed. Beatrice suffers in act 4, but one act later learns that Freevill is alive after all; one could interpret her distress as temporary, then, and tempered by the happiness she presumably feels at being reunited with him. Although she has perhaps become wiser to the manipulation of which he is capable, and to his habit of frequenting brothels, she nevertheless 
accepts him back as her betrothed husband. ${ }^{11}$ Mulligrub and Malheureux ultimately escape their threatened deaths, and so, in a literal physical sense, no real harm comes to them.

Even then, as with Franceschina, Mulligrub could be said to deserve the public humiliation and moment of terror with which he is punished in act 5 . Though he is technically not guilty of the crime for which he is directly condemned - stealing Cocledemoy's cloak - he is also not innocent. When Cocledemoy reports him to the officers in 4.5, the trickster tells them: 'He's a strong thief. His house has been suspected for a bawdy tavern a great while, and a receipt for cutpurses, 'tis most certain. He has long been in the black book, and is he ta'en now?' (1204). We should remain slightly dubious of Cocledemoy's characterization: he is, after all, out to humiliate and punish Mulligrub. We have no evidence beyond his statement here that Mulligrub has been written up as a criminal in Newgate prison's 'black book', nor that the Mulligrubs' tavern is widely known to double as a fence or a brothel (although Mistress Mulligrub's willing promise that in her widowhood she will 'have a piece of mutton [a commonplace innuendo for women's flesh] and a featherbed for [Cocledemoy] at all times' [5.3.100-3] certainly hints at some degree of truth behind this latter claim). We learn from the couple themselves that the Mulligrubs engage in criminal practices. When Mulligrub discovers that Cocledemoy has robbed him in act 2, his wife soothes him, telling him the financial loss is easily recoverable: "tis but a week's cutting in the term' (2.3.119). Although 'cutting' here might refer to cheating customers in a general sense through overcharging them, picking pockets, or other such cons, Mistress Mulligrub probably refers to the specific crime of adulterating wines by 'cutting' them with water. Cocledemoy suggests he suspects the Mulligrubs of an even more dangerous form of cutting - where the Mulligrubs import and serve inferior foreign and heterodox wines, thereby diluting the good English Protestantism of their customers' characters. Cocledemoy accuses the vintner of having made the Londoners

drink of the juice of the Whore of Babylon, for whereas good ale, perries, braggerts, ciders, and metheglins was the true British and Trojan drinks, you ha' brought in popish wines, Spanish wines, French wines ... both muscadine and malmsey, to the subversion, staggering, and sometimes overthrow of a good Christian. (5.3.113-21)

Adulterating wine was a criminal offense in early modern England. ${ }^{12}$ But Cocledemoy's charge at the gallows frames Mulligrub's moral failings as even more criminal and worthy of punishment than everyday fraud - they are a danger to the 
very moral fabric of London, and we can perhaps feel at ease about deriving comic pleasure from his pain.

The accusations Cocledemoy launches at Mulligrub are, of course, disturbing because tinged with xenophobia and religious intolerance. Mistress Mulligrub hints in act 3 that the couple may be associated with the 'Family of Love' (3.4.6), a radical Dutch sect that settled in England following persecution at home, and that Londoners anxiously imagined as practicing free love. Cocledemoy specifically levels his charge in terms that connect the Mulligrubs to foreign faith (Catholicism) practiced by two of England's greatest political rivals (the Spanish and French). Not only are the Mulligrubs connected with a heterodox Protestant sect, but they are also bad at their own religious practice. When Mulligrub returns home in act 3 to find his wife dressed up for dinner, he asks, 'Whither are you a-gadding?' (3.4.121). 'Gadding' within Puritan faith referred to the practice of moving 'transgressively across Parish borders, in order to consume the heated speech of noted preachers, and have their hard hearts softened'. ${ }^{13}$ But Mulligrub uses the term in its more secular sense of 'go[ing] ... aimlessly or idly ... in the pursuit of pleasure.' ${ }^{14}$ The Mulligrubs live up to orthodox suspicions that the Puritan practice of gadding mimics 'the social disorder provoked by the public theatre.'15 Beyond her single reference to tobacco not being in use in the Family of Love (3-6), Mistress Mulligrub shows almost no interest in the practices of her faith; instead she gives all of her attention to secular social climbing: her elite social connections (3.3.21-6), her 'gentle' background (3.4.9-10), her delight in wielding sophisticated language $(3.3 .33-5 ; 3.4 .10-12)$, and ensuring that everyone knows her status is better than that of her neighbour (3.3.8-11). This representation suggests that those of different faiths are not only more prone to immorality but also generally unfaithful even in their heterodoxy. The association thus plays into the problematic trope of the ethnic or religious 'foreigner' who is also morally inferior and criminal. This trope reads troublingly on a modern stage, where laughing at the punishment of the criminal Mulligrub also possibly implicates audiences in laughing at the play's marginalized 'others'.

Although this essay focuses primarily on Mulligrub, Beatrice, and Malheureux - figures who have drawn less critical attention as operating in potentially complex comic registers - these questions probing the ethics of laughter are also especially urgent when thinking through responses to Franceschina. The eponymous Dutch courtesan unites problematic beliefs about women (that they are inherently unchaste), about religious 'others', and about foreigners (that they are prone to deceit, irrationality, murder, etc). The Toronto production staged Franceschina's anger in a way that, to my eyes, ironically highlighted the fiction of 
the angry foreign woman: particularly in 2.2.221-6, where she outlines her plan to murder Freevill and Malheureux, a speech which concludes 'Women corrupted is the worst of devils'. Flora Quintus's Franceschina, dressed in black corsetted bodice, short hot-pink silk skirt, and black fishnets, stood downstage; leaning and pointing aggressively into the audience, she spoke her lines with a delighted vengeance, under a comically red spotlight. She was immediately recognizable as the fantasy of the dangerous woman scorned. In some ways, Quintus's Franceschina was as much a cartoonish trope as Belerique's Mulligrub, but with additional layers of irony interrogating the truth of that trope. The Toronto Courtesan was constantly sliding between modes of representation - at times appearing to reiterate and reinforce the image of the devilish (foreign) woman, at other times, calling the truth of that representation into question. It became difficult to know, amidst these slippery representational modes, whether we were laughing at Franceschina because she confirmed what foreign women 'are like', while caustically looking forward to the moment of her downfall and punishment, or whether we were laughing at the outdated misogyny and xenophobia underlying the fantasy of the vengeful woman itself.

Returning to the Mulligrubs, act 5 scene 3 presents an additional problem for modern productions in that it demands staging Mulligrub's and Malheureux's responses to learning they have been deceived. Both men remain on stage immediately following their reprieve, requiring the actors playing them to perform a visible but silent emotional reaction to the punishment they have just (almost) experienced. Contemporary actors used to working in the Stanislavskian or American styles might be tempted to think about how they would feel in real life if they had just spent a night in prison believing they were about to die only to face a sudden reprieve. The 'realistic' psychological response might be imagined as an uncomfortable mixture of terror, relief, joy, anger, and shock from which they would not immediately recover. One can imagine playing out the scene in this mode, so as to render its concluding 'mirth' deeply anxious and painful.

The obvious response to this thought experiment, of course, is that early modern plays - and particularly the Mulligrub-Cocledemoy plot of The Dutch Courtesan - simply do not operate in this realistic comic register. In a public rehearsal workshop on 23 February 2019, we discussed the comic mode to which Mulligrub belongs: he is essentially a clown/cartoon figure, who endures repeated physical humiliation: lathered in soap and left sitting alone, unseeing, with a coxcomb on his head in the act 2 shaving scene, ${ }^{16}$ manhandled and put in the stocks in act 4, and finally brought to the gallows where he publicly confesses his faults in front of his community. In response to Cocledemoy's repeated tricks, 
the Toronto production's Mulligrub became increasingly, hilariously angry even as he occasionally tried to reclaim his dignity and composure through, for example, comically exaggerated deep breathing and a smile so painfully put-on that it only revealed how eaten up he remained inside. Alan Belerique playing the foolish vintner invited us to view (and laugh at) Mulligrub as an outrageously excessive and impotent comic fool. His performance relied on the audience maintaining its distance from Mulligrub so that through our laughter we aligned ourselves with the socially decorous norms that Mulligrub breaches with his excessive anger, and distanced ourselves from his foolishness. ${ }^{17}$ Mulligrub's anger leads him to obsessively concoct revenge fantasies against Cocledemoy, which of course renders him distracted and more vulnerable to Cocledemoy in future encounters. Mulligrub's cartoonishness fosters this distance between Mulligrub and the audience. Although we see Mulligrub in repeated painful/embarrassing physical situations, he never seems truly harmed by his experiences, but comes back in subsequent scenes, physically whole and ready for more humiliation. The production's casting bolstered this comic effect: Belerique, a white-presenting man, was one of the tallest and most imposing members of the cast. ${ }^{18}$ His size added to the exaggerated humour with which he stomped around the stage, ultimately throwing into relief just how impotent his masculine rage was. In the arrest scene in 4.5, the fact that two of the play's three constables were played by women of colour - Elvira Tang and Cheryl Cheung - both of whom also appeared smaller and less imposing next to Belerique, mitigated further the problematic aspects of seeing one of the play's 'foreign'-connected characters taken in on dubious charges. The two had already established themselves as charming figures, endearingly playing rock-paper-scissors against each other rather than keeping careful watch and enthusiastically throwing themselves into their role as 'Upstanding Constable' in their eager arrest of Mulligrub. In rehearsals, Noam Lior discussed this scene as potentially fraught, given that it showcases the arrest of a religious minority in a production staged in a modern city in North America where wrongful incarceration, overly punitive sentences, and police violence disproportionately affect minority populations — particularly men of colour. The Toronto casting effectively reversed the usual power dynamics of arrest. Belerique's Mulligrub, flanked by the two tiny constables, appeared to be in no real danger, leaving us free to laugh at his angst. The scene, then, perfectly aligns with Escolme's discussion of Laurent Joubert's prescriptive and ethical position on comic laughter in his Treatise on Laughter (1579); Joubert presumes that audiences will only laugh at 'light and inconsequential mishaps and improprieties' and not at circumstances where 'its subject is likely to be seriously pained'. ${ }^{19}$ 
Because Mulligrub is 'properly punished for his foolishness and unpleasant foul deed', his near-hanging might read, in Joubert's context, as an example of a 'light and small' hurt that 'reinforces laughter'. ${ }^{20}$ Indeed, Joubert's theory lines up with how Daniel Coo, who played the Toronto Courtesan's Cocledemoy, read the Mulligrub-Cocledemoy plot. When asked at the rehearsal workshop whether he viewed Cocledemoy's treatment of Mulligrub as cruel, Coo answered no, because Cocledemoy is teaching Mulligrub a necessary lesson about not cheating members of the community. Coo understood Cocledemoy as a reformative character, akin to the virtuous allegorical figures in a morality plot. Coo's view was supported, he felt, by the fact that Cocledemoy — though he definitely enjoys the game of outwitting and stealing from other characters - ultimately returns all of the items he steals. When Tisefew labels him a 'knave' along the same vein as Mulligrub, Cocledemoy responds, 'No knave, worshipful friend, no knave! For observe, honest Cocledemoy restores whatsoever he has got, to make you know that whatsoe'er he has done has been only euphoniae gratia - for wit's sake' (5.3.146-9). Recent editions have Cocledemoy return the goblets at this point; the Toronto production had him throw a large sack filled with all his stolen goods on the ground. Whether we believe that he intended to return the stolen goods all along - or only does so when publicly confronted about his stealing is up to our own interpretation, but we can certainly make the argument that the Mulligrub-Cocledemoy plot is a comic morality plot where the actors are clownish tropes rather than realistic figures capable of lasting psychological harm.

The preceding, however, does not leave me feeling entirely easy about the Mulligrub-Cocledemoy plot. While watching the production I found myself earnestly laughing at the clown plot elements - both because the actors carried them off skilfully and because, I'm sure, I was primed to laugh at the recognizably comic structures of the Mulligrub-Cocledemoy scenes. ${ }^{21}$ When I pass through the moment of immediate laughter and think about who I am laughing at, however, I am again troubled, both by the ease with which the onstage clowning can hide the (xenophobic?) implications of what is being laughed at and by concerns that the audience around me might be misreading the production's aims to satirize the play-text's misogynistic and xenophobic articulations. I worry over the potential harm audience laughter might cause those in the audience who occupy the same social position of the Mulligrubs, Franceschina, or Mary Faugh.

Noam Lior's essay in this issue outlines an alternate mode of producing the Mulligrub plot that highlights the psychological torment the vintner experiences at the gallows. I think the particular casting and emphasis on clowning throughout the Toronto production limited the emotional pathos available to Mulligrub 
when he confronted his mortality — I myself experienced a mostly pleasurable schadenfreude at Mulligrub's comical distress. But the play also effectively rounds back on the Mulligrub plot in a way that invites us to reconsider the justice of its events by paralleling Cocledemoy and Freevill (the play's two tricksters) and offering, in the Freevill plot, a trickster narrative funny in almost exclusively anxious modes. In the main plot, a trickster (Freevill) teaches a fallen man (Malheureux) to repent of his sinful appetites by the threat of imminent execution. Reading this plot alongside the seemingly lighter Cocledemoy-Mulligrub plot challenges the easiness of our earlier laughter and invites us to consider whether, even if Cocledemoy's tricks cause no lasting physical harm, they are not as 'hurtless' as he tries to persuade us.

\section{'Dear woes cannot speak': Laughing at Beatrice}

The play's main plot featuring Freevill, Malheureux, Franceschina, and Beatrice is far from 'hurtless'. Freevill cruelly employs the same disguising and trickery that Cocledemoy uses on the Mulligrubs to torment Franceschina, Malheureux, and Beatrice. The latter is especially heinous given that Beatrice is arguably the play's true moral centre. Freevill's treatment of Beatrice is further symptomatic of his inability to function harmoniously within a community. Rather than using his wits and the power of laughter to unite, he deploys these things solely to humiliate and punish foes (like Franceschina) and friends (Beatrice and Malheureux) alike.

The presence of Beatrice, however, particularly complicates Courtesan's main plot, which operates in the register of Jacobean city comedy. City comedy, set predominantly in London (or, as in Jonson's Volpone, in an obvious analogue for London), focuses on themes of economic competitiveness and exploitation; cuckoldry and sex work; immigration and global trade; and the general conditions of life in crowded urban centres, including poverty, disease, and pollution. Middleton's city comedies generally adopt a warmer attitude towards urban communities and their problems, with plays like A Trick to Catch the Old One and A Mad World, My Masters dramatizing the forgiveness of sexual promiscuity and families taking part in practical and felicitous cuckoldry that enables wealth to be shared amongst the community. Jonson and Marston adopt a more cynical view of city problems, whereas Middleton sticks to having would-be exploiters and egotistical social climbers as the butt of city comedy competitiveness and exploitation. In Jonson's Volpone, for example, the Avocatori of Venice separate Celia from her wealthy abusive husband; rather than granting her autonomy, however, they send 
her home to her father (her dowry trebled), perhaps to be married off for social and economic gains once again.

Surrounded by scheming and competitive men and women, Beatrice fits awkwardly into the community of The Dutch Courtesan. Her fiancé enthusiastically defends the virtues of brothels and resists her encouragement 'not to be extreme' (2.1.49) in his expression of love and desire. Even her own respectable sister freely lambastes undesirable but persistent suitors with vulgar references to their 'gooseturd-green teeth' (3.1.21) and asserts that 'I had as lief they would break wind in my lips' (24-5). Beatrice's commitment to her rational love and to 'severe modesty' (36) seems inexplicable. Indeed, the 'feisty-but-chaste' maid Crispinella who speaks her mind, rejects suitors at will, and refuses to be bound by conventions of complete and sober chastity is a recognizable and often celebrated figure of city comedy. ${ }^{22}$ Beatrice's severe modesty already risks feeling out of date to progressive younger modern audiences that hold more positive views around women and sex; but her attitudes seem out of date even by the norms of early modern drama. ${ }^{23}$

Modern actors might be tempted to render Beatrice's conservatism risible, inviting the audience to laugh at her too-sweet and naively forgiving nature and pointing out her incongruity in the play's vulgar environment. The Toronto Courtesan production did garner some humour from her too-good persona in the 4.4 confrontation between Franceschina and Beatrice. Carmen Kruk played Beatrice at this moment as earnestly, tearfully distraught, and yet the scene was funny. Part of the comicalness came from Lior's direction that Kruk deliver Beatrice's response to Franceschina's revelations, 'I think you say not true' (4.4.75), as though 'this were the meanest thing Beatrice has ever said in her life' (my paraphrase). The humour lies in Beatrice's underwhelming ability to fight back in the play's cruel urban environment, an inability that renders her at once pathetic and sympathetic. Franceschina's response to Beatrice's too-gentle nature, however, garnered the rest of the humour in the scene. Franceschina delivers the news in person with the cruel aim of causing Beatrice pain (2.2.224; 5.1.96-9). While she does succeed in upsetting Freevill's fiancée, she fails to provoke in Beatrice the same gross anger that makes Franchechina herself now revolting to Freevill and Malheureux. Instead, Kruk's Beatrice tearfully offered to 'love [Franceschina] the better' since she 'cannot hate what [Freevill] affected' (4.4.59-60). Quintus performed Franceschina's reaction to Beatrice's generosity with hopping frustration: Beatrice's goodness proves unexpectedly, hilariously powerful, and we laugh in her service, even as we feel pleasurable pity for her sorrow. ${ }^{24}$ 


\section{'[L]est [war] should come home to their own doors': Men's Violent Communities}

The unexpectedly strong pathos of Kruk's Beatrice threw into relief Freevill's cruelty. The Toronto production attempted to avoid, if possible, reducing Beatrice to a comic trope à la Mulligrub and Cocledemoy in order to explore the play's possible critique of men's hypocritical treatment of women. Elsewhere in this issue, Meghan Andrews observes that Marston's play takes up the Patient Grissil/ Griselda romance narrative, where a husband tests his wife by subjecting her to increasingly painful experiences (including taking away her children, 'divorcing' her, and forcing her to serve at the wedding of his supposed new bride). The patient Griselda narrative tests a wife's willingness to uphold those three virtues most commonly associated with ideal women: chastity, silence, and obedience. Women's lack of chasteness in city comedy might have justified Freevill's test ${ }^{25}$ except that in the famous Boccaccio version of Griselda, the narrator concludes by characterizing such tests as already outmoded in the fourteenth century: 'Who but Griselda could have suffered dry-eyed and with a serene countenance the harsh and unprecedented proofs that Gualtieri put her to? It would have served him right if he had come upon a wife who, when he turned her out of doors in her shift, had found another man to shake her skin and even provide her with a new dress in the bargain. ${ }^{26}$ Freevill's testing of Beatrice is old-fashioned, hypocritical (given his own lack of chaste behaviour that risks bringing 'unsound'ness into the newlyweds' marriage bed), and seems particularly cruel given that he does not appear at all anxious that she might cuckold him. In his defence of the brothels in 1.1, he seems more worried that men (like him) will bring the threat of cuckoldry into his home than that Beatrice will go out whoring. The brothels are necessary because they keep other men busy and away from the house where Beatrice is chastely ensconced. His reasons for 'testing' her by telling her that Freevill is dead seem designed merely to arrange a pleasurable spectacle for his own eyes:

I will go and reveal myself — Stay! No, no!

Grief endears love. Heaven, to have such a wife

Is happiness to breed pale envy in the saints!

Thou worthy dove-like virgin without gall,

with what a suffering sweetness, quiet modesty,

Yet deep affection, she received my death!

And then with what a patient, yet oppressed kindness 
She took my lewdly intimated wrongs.

Oh, the dearest of heaven! (4.4.88-99)

In this moment, her pain becomes his pleasure; he delights at seeing the extent of her grief and love for him, and even decides to extend the period of her suffering to manipulate her into being even happier when she finally learns that he is still alive (with perhaps the added benefit that her relief and joy will prompt her to forgive his 'lewdly intimated wrongs').

This moment highlights Freevill's role as a Machiavellian director who uses his wits to arrange painful encounters between his friends and acquaintances and who takes pleasure in watching the drama of other people's sufferings. His delight in Beatrice's sorrow echoes his earlier eavesdropping on Malheureux in 1.2. Having introduced the celibate Malheureux to the stunning Francheschina, Freevill secretly watches his supposed friend's struggles to understand and cope with his newfound and painful desire, gleefully noting 'he's caught. Laughter eternal!' (1.2.155-6) before emerging to mockingly parrot Malheureux's praise of Franceschina back at him.

In his director's talk presented at the 'Sex, Religion, and Xenophobia' conference in March 2019, Lior articulated that one aspect of the play he had been thinking about through the production was the way that adolescent boys are given very little guidance for navigating confusing and powerful feelings - including incipient lust - and instead learn to cope with their confusion via teasing and cruelty. Men having failed to learn to engage with each other openly and honestly, and thus connecting with others only in ways that are cruel and humiliating, has shaped adult masculinity. Lior located this discussion in the context of the Children of the Queen's Revels, the boy company who performed The Dutch Courtesan, but his comments are equally helpful in making sense of the comic motions of the play within the genre of city comedy, where characters - particularly men - compete for social and economic superiority. His comments drew my attention to how the community of men in the play is fractured, competitive, and rooted in violence and humiliation.

When Kruk's Beatrice heard the news of Freevill's death and betrayal, and asked Crispinella in a shatteringly devastated tone, 'Sister, shall we know each other in the other world?' (4.4.74), Brianna Maloney as Crispinella held Kruk/ Beatrice's hands in deep concern. 'What means my sister?' she replied, all traces of her earlier sharp tongue utterly abandoned. In the February rehearsal workshop, when Maloney's unavailability led us to cut all of Crispinella's lines from this scene, Kruk revealed that the new text, with Crispinella's lines removed, had 
the unintended effect of heightening the emotional difficulty of performing this scene, as it suddenly felt like Beatrice was alone in her grief. Indeed, with the exception of 2.1, where Freevill serenades Beatrice, the two sisters always appear together on stage - usually in their private rooms with their nurse Putifer. They offer us a sense of closeness, support, and friendship between the two sisters lacking in the play's male-dominated scenes.

Act 1 scene 1 introduces nearly all of the play's men (excepting Cocledemoy, Sir Hubert, and Sir Lionel) together in one go. This scene affords a production the opportunity to clearly mark out the men's characters, motives, and their closeness to one another through symbolic blocking. In the Toronto production, Mulligrub entered with Freevill and Malheureux flanking him, clapping his back and laughing uproariously while the vintner scowled. Tisefew and Caqueteur followed behind, and the four young gentlemen pantomimed around Mulligrub the story of Cocledemoy, Mary Faugh, and the blind harper in the tale of the Mulligrubs' stolen goblets. Mulligrub stood in the centre as the lads took turns playing their roles in the story and laughing mockingly when not performing. Clearly Mulligrub, though well-known to the young men, was not a part of their community. Humour and laughter in this instance marked off lines of inclusion and exclusion in the male community. ${ }^{27}$ Once Mulligrub had departed, the group of men broke down even further, with Tisefew and Caqueteur, standing downstage, their backs to Malheureux and Freevill, holding a private conversation about Tisefew's ring (a prop tied to the competition over Crispinella). They departed shortly after, leaving Freevill and Malheureux alone on stage to discuss the merits of brothels. The scene laid out the tiers of relational closeness amongst the men of the play while also laying bare the fault lines dividing them. Following this scene, the men do not appear all together on stage until the masque in act 4 , and then again in the resolution at the gallows. When they do meet, in pairs and triplets, they often do so as competitors: Tisefew and Freevill visit the sisters together in 3.1; when Caqueteur joins them later in the scene, Tisefew warns Crispinella that he is approaching as his love rival. The two men (albeit at Crispinella's behest) hide themselves to watch her set him up in a braggadocio lie — at which point they jump out of hiding to laugh at the embarrassed Caqueteur, once again using laughter as a means of marking lines of social dominance. Within this interaction Tisefew and Freevill appear tied in their social standing — and in some ways they are foils to one another as the play's two successful young suitors. They seem, nevertheless, to have very little in the way of friendship - they are mostly apart from each other throughout the play and though they end the play as brothers-inlaw, they never address each other in fraternal terms. 
The young men's relationship with Cocledemoy is similarly cold. Although Freevill and Cocledemoy too are parallels of each other, occupying a similar position as the witty trickster of the main and sub plots, the two are not in any way close. Cocledemoy almost never interacts with the younger men - meeting them only in 1.2 and 5.3. Moreover, Cocledemoy, with his bawdy songs ('Maids on their backs / Dream of sweet smacks' [4.5.75-6]), vulgar expressions ('I'll make him fart crackers!' [143]), and nights spent drinking at pubs with courtesans, belongs to a cruder social class than Freevill and Malheureux. In the Toronto production the groups were further marked apart along age line, with Coo being visibly older than Eldridge, George Worrall (Malheureux), Ross Slaughter (Caqueteur), and Victoria Urquhart (Tisefew). The Toronto Courtesan played out the meeting among Freevill, Malheureux, and Cocledemoy in 1.2 in a way that highlighted the power differentials between them. When Freevill and Malheureux entered, Cocledemoy was crawling on the floor. Moments earlier, he had bent (arthritically) to kiss Mary Faugh's foot, and then, startled by Malheureux and Freevill's presence, had toppled over. When Eldridge as Freevill delivered the warning that Mulligrub was seeking revenge against Cocledemoy, he first stood over him smugly and then knelt condescendingly to wag his finger at the clown's exploits. The scene conveyed Freevill's superiority over Cocledemoy as well as his detached enjoyment at watching Cocledemoy and Mulligrub compete to outwit each other without caring who won.

Male community in Courtesan is based on competition. Just as Freud predicts, laughter is a symptom of this competition and is always levelled against someone. Someone is always winning and always losing in the men's jokes. Nowhere is this phenomenon more apparent than in the relationship between Freevill and Malheureux. Some critics have argued Freevill is the play's hero and moral centre, ${ }^{28}$ but while he occupies a similar position in the main plot as Cocledemoy in the subplot, I am not as convinced that his tests and tricks are reformative in the same way that Cocledemoy's might be charitably read. One might argue that in his rigid rejection of courtesans and sexual desire, Malheureux falls victim to irrational excess that needs tempering. But Freevill does not try to break Malheureux from his celibacy by means of lawful married love or desire; rather, he overwhelms him with a different form of excess - the unlawful and potent sexuality of the courtesan. He then watches Malheureux painfully struggle with the desire that overwhelms his very sense of self. Seeing the play on stage drew my attention quite sharply to the number of times Malheureux articulates his sense that he has lost himself-'I am / No whit myself' (2.2.75-6); 'I am not now myself, no man' (4.2.28) — or worries he may be out of his mind — 'I must not rave' (2.2.97). He 
describes himself as 'taken uncollected suddenly' (194), and dwells on the failure of his reason: 'my lust, not I, before my reason would' (3.1.195); 'There is ... no reason in desire' (4.2.11-12). Only once he has escaped hanging can he finally say, 'I am myself' (5.3.65), in some relief. Malheureux's plight on stage was funny, largely owing to Worrall's earnest and boyish performance. But this portrayal was mixed with pathos, as, articulating his confused inner state with pained expression and anxious tone, he seemed deeply wounded by the lust that threatened to undo his sense of self.

His pain took on an increasingly distressed urgency following Franceschina's temptation of him to commit murder. Malheureux battles with self-loathing: 'man's but man's excrement, man breeding man / As he does works' (2.2.228-9). While he appears to find relief in his decision to tell Freevill 'all' (253), this decision tips Freevill and Malheureux's relationship from what might be described as adolescent bullying into the genuine threat of violence as Freevill suddenly realizes that city comedy's competition and deception could be turned against him. (That is, if Malheureux had been persuaded by Franceschina, he might have schemed against and murdered his best friend for sexual gain.) Following Malheureux's revelation, Freevill adopts a less light-hearted view of courtesans, now describing sex with Franceschina as repulsive, like sleeping with a 'statue, a body without a soul, a carcass three months dead' (2.1.137-8) where previously he had praised her as 'pretty, nimble-eyed Dutch Tannakin; ... a soft, plump roundcheeked froe that has beauty enough for her virtue, virtue enough for a woman, and woman enough for any reasonable man' (1.2.158-62). When Malheureux rejects Freevill's invitation to abandon his desire for Franceschina, Freevill decides to punish his friend, with a swiftness and lack of hesitation that suggests he is latching onto any excuse to humiliate his friend. When we next see Malheureux he is being set up to be arrested and murdered.

The scenes in which Malheureux is arrested and nearly hanged were still funny in the Toronto Courtesan. When Malheureux attempted to persuade Franceschina of how he had murdered and disposed of Freevill's body, he adopted a weak imitation of a heroic manly pose that was clearly and humorously unconvincing even to himself. Worrall's bewilderment foregrounded the comic potential of the others on stage, as the crowd of eager Constables, Tisefew (documenting his confession on his mobile phone), ${ }^{29}$ the delighted Franceschina, and angry Sir Lionel Freevill erupted from their shared hiding space and collared him. Worrall continued to play the scene with an earnest boyishness that made him seem comically small and impotent. Poor Malheureux's lust had landed him in an extremely inconvenient situation! 
But this same boyishness deprived Worrall's Malheureux of the invulnerability of Belerique's cartoonish Mulligrub and lent a fragile pathos to the character that made my laughter at him anxious. I grew increasingly uneasy as Malheureux faced the noose with that very layer of psychological realism that was absent in the play's clown subplot. This Malheureux felt a real and lasting fear of his impending death. When Freevill, at the last possible moment, revealed that he was alive after all (with a wide grin and an extremely jaunty 'farewell!'), the audience laughed but the easy comedy was undercut by Worrall's reaction to the news: a mixture of stunned disbelief, relief, and then, as he joined the play's upper-middle-class characters on the balcony, sadness. Freevill and Tisefew took the hands of their soonto-be-brides in a moment of joyful reunion, but Malheureux stood apart, clearly still processing his recent traumatic experience. He reluctantly understands, in these moments, that his closest friend has played a violent joke on him, viciously turning Malheureux's entire community against him, bringing him to the brink of death, and forcing him to humiliatingly lay bare his lust and terror in a public forum.

Haunting this scene, moreover, is the real and deadly possibility that Freevill might not have revealed himself in time if he had so desired. Freevill's merry laughter in the face of his revelation as 'best trickster' is a violent act towards Malheureux. These are not the actions of a man simply concerned with leading his friend away from moral danger. This is Freevill's revenge for Malheureux's daring — for even a moment — to think that he could betray Freevill and murder him for personal gain. Freevill demonstrates that, in the city comedy competition, he has the best wit and the most control. Freevill is the one who draws the outlines of the community, the boundaries of friendship, and the limits of the joke.

I can, of course, only make claims about the direction of my laughter throughout this production - and I acknowledge that my familiarity with the play throughout its rehearsal process has deeply shaped my laughter, pleasure, and anxiety. I have no way of telling if other audience members laughed with similar anxiety at Malheureux and Beatrice's pain. Others in the audience may have chosen to align themselves with the direction of Freevill's laughter, and derived pleasure from his cruelty. Seeing the play in a production that sought to balance and explore both early modern and contemporary modes of humour, however, demonstrated to me the play's potential — driven by its multiply layered and jostling comic modes - to reflect on the work of laughter in creating and dividing communities, committing and repairing violence, and defining ethics and values. ${ }^{30}$ As audiences shift between the comic modes and emotional registers of the play in production, they are likely to discover parallels between scenes 
that seem more innocuous (the Mulligrubs) and ones that are more overtly cruel (Freevill, Malheureux, Franceschina, and Beatrice) and, through these parallels, become aware of what they are laughing at and the costs of that laughter. While we will never know how early modern audiences responded to the play, arguably these same jostling comic juxtapositions were also available to audiences then, and audiences in 1604 may have been similarly moved to reflection. 


\section{Notes}

I would like to thank the cast of the Toronto Courtesan for their thoughtful and hard work throughout rehearsals and production. Their insight into the play's characters and tone have allowed me to think more complexly about the text and its interpretative possibilities.

1 Albrecht Classen, ed., Laughter in the Middle Ages and Early Modern Times (Oxford, 2010), https://doi.org/10.1515/9783110245486.

2 Bridget Escolme, Emotional Excess on the Shakespearean Stage: Passion's Slaves (London, 2014), 59-62, 67-8, https://doi.org/10.5040/9781408179703; John Morreall, Comic Relief: A Comprehensive Philosophy of Humor (Chichester, 2009), 4-8, 11.

3 Henri Bergson, 'Laughter', in Comedy, ed. Wylie Sypher (New York, 1956), 66ff; Sigmund Freud, Jokes and their Relation to the Unconscious [1905], https://www.SigmundFreud.net, 108-9, 122.

4 Freud, Jokes, 73.

5 Although even here laughter is unstable: what if, for example, an immigrant woman is also sitting in the audience of a play where one of the final 'jokes' appears to be that of an immigrant being arrested and led off stage to be whipped? Such an audience might be divided rather than unified in their responses, with some participants aligning with the marginalized characters who are the objects of the play's jokes.

6 Classen, ed., Laughter, 265, 165, 201, 215, 429.

7 Nicholas Ridout, Stage Fright, Animals, and Other Theatrical Problems (Cambridge, 2006), 136, https://doi.org/10.1017/cbo9780511617669.

8 Ibid, 142.

9 Escolme, Emotional Excess, xxv-xxxiii. Escolme's work has also been invaluable in helping me unpack the complicated and contradictory modes of humour in Marston's play. Her chapter on comedy astutely sums up the difficulties we face in attempting to theorize how early modern laughter operated, rightly noting that comedy and laughter are culturally situated and laden with competing and differently affective responses (56). I would emphasize the extent to which laughter is personally situated. My experience researching sexual violence in contemporary performances has led to several instances where aspects of plays that made me distinctly anxious (jokes rooted in rape humour, for example) left me feeling alienated from what appeared to be collective audience laughter. Even when the dominant aesthetic and cultural trends direct a largely shared affective response, there are unpredictable responses of resistance and difference. We cannot - even if we conduct audience surveys - ever fully know what people are laughing at, or why. If we cannot know 
what a large audience with diverse cultural and experiential backgrounds is laughing at now, then how can we begin to understand what an audience might have been laughing at more than 400 years ago?

10 John Marston, The Dutch Courtesan, ed. Karen Britland (London, 2018). All further references to the play are to this edition.

11 Alternate possibilities are available in production, however; as with Isabella in the concluding moments of 5.1 of Measure for Measure, Beatrice here has no written lines that provide cues as to how she is feeling after witnessing Freevill's cruelly didactic revelations; nor does the scene give any indication as to the nature of Freevill and Beatrice's interactions in its final lines. Does she find herself disturbed or even repulsed by his humiliation of Malheureux here and accept Freevill with less eagerness than she did in 5.2? The default assumption, based on her 'wonder' (5.2.58), is that she fully recovers from her pain, but as this essay and the Toronto Courtesan demonstrate, more emotionally complex responses from Beatrice are possible that interrogate the presumed happy ending.

12 Joshua Scodel, Excess and the Mean in Early Modern English Literature (Princeton, 2009), 204, https://doi.org/10.1515/9781400824939.

13 Simon W. du Toit, “A Greedie Desire”: Performing Puritan Passion', Ecumenica: A Journal of Theatre and Performance 2.2 (2009), 68.

14 Oxford English Dictionary (OED), s.v. 'gad', v. 1.

15 du Toit, “A Greedie Desire”, 68.

16 In Q, Cocledemoy instructs Mulligrub to shut his eyes to keep out the suds, and then places a coxcomb on his head; the Toronto production replaced the 'coxcomb' with a shower cap that Cocledemoy comically pulled down over Mulligrub's eyes like a blindfold.

17 Classen, Laughter, 5. Of course, as Classen points out, some audience members may laugh sympathetically or self-deprecatingly as they recognize themselves in the object of laughter.

18 I use the terms 'white-presenting' and 'male-presenting' to acknowledge that my reading of this scene rests on my own interpretations of the actors' bodies, while acknowledging that the actors themselves may identify, in terms of both gender and race, differently and more complexly than I have read them. To me it seemed that the Toronto Courtesan's casting - with the officers as petite women of colour and Mulligrub as a large, white-presenting man — inverted and tempered some of the potential tragic violence of the scene.

19 Qtd in Escolme, Emotional Excess, 60.

20 Qtd in Escolme, Emotional Excess, 61. 
21 Freud, Jokes, 137, argues that a person being placed in a recognizably comic situation can be enough to elicit our laughter and render that person a comical object.

22 The fact that these criticisms resonate tonally with both Beatrice's earlier warning to Freevill in 2.1 that he not 'deceive' her (1.2.53) and with Franceschina's condemnation of men's hypocrisy regarding women and sex ('De very enjoying us loseth us; and, when you ha' made us hateful, you only hate us' [2.2.132-4]) validates, in my eyes, a production or critical reading of the play that satirically punctures any earnest presentation of Freevill as the play's moral centre. For a concise review of critics who have read Freevill as the play's moral hero, see William M. Hamlin, 'Common Customers in Marston's Dutch Courtesan and Florio's Montaigne', Studies in English Literature 1500-1900 52.2 (2012), 112, https://doi.org/10.1353/sel.2012.0015.

23 Beatrice's commitment to chastity is nevertheless understandable, however, when we consider comedies like Much Ado and Volpone where the punishments for women suspected of infidelity are severe, ranging from defamation and physical assault to (in the case of Volpone's Celia) sexual violence. Claudio casts Hero off, in many productions throwing her bodily to the ground, and she ends up having to stage a funeral before she can metaphorically rise with a clean reputation. Corvino threatens Celia with physical imprisonment and what the play heavily implies to be anal rape, for the 'crime' of waving her handkerchief at an apparent apothecary, in her attempt to secure a cure for her husband's jealousy. Even Freevill articulates his expectations that, unlike him, Beatrice should remain chaste, when he anxiously defends brothels as a means to shore up the privacy of his own sexual property.

24 This moment provides a rebuttal to Bergson, 'Laughter', 63, who argues that pity and laughter are mutually exclusive.

25 On this topic see particularly Richard Horwich, 'Wives, Courtesans, and the Economics of Love in London City Comedy', Comparative Drama 7.4 (1973-4), 291309, https://doi.org/10.1353/cdr.1973.0024.

26 Giovanni Boccaccio, Decameron, trans. J.G. Nichols (New York, 2008), 647.

27 Classen, Laughter, 3.

28 Carol Pollard, 'Immortal Morality: Combinations of Mortality Types in All's Well That Ends Well and The Dutch Courtesan', Cahiers Elisabéthains: A Biannual Journal of English Renaissance Studies 25 (1984), 53-9, https://doi. org/10.1177/018476788402500108.

29 While I am using male pronouns here to maintain consistency for ease of reading, in the Toronto production Victoria Urquhart played Tisefew as a woman.

30 See Michael Cordner's essay, 'The Dutch Courtesan and 'The Soul of Lively Action', in this issue, on the unresolved chaos of the play. 
